\title{
Effects of different level of leaf removal applications on mineral substance of raisins in organic Sultani Çekirdeksiz grape growing
}

\author{
Fadime Ateş ${ }^{1, a}$, Akay Ünal $^{1}$, Çiğdem Takma², and Ahmet Altındişli ${ }^{3}$ \\ ${ }^{1}$ Manisa Viticulture Research Institute Manisa, Turkey \\ ${ }^{2}$ Ege University, Faculty of Agriculture, Department of Animal Science, İzmir, Turkey \\ ${ }^{3}$ Ege University, Faculty of Agriculture, Department of Horticulture, İzmir, Turkey
}

\begin{abstract}
. 311.595 hectares of organic grapes are grown, which constitutes 4.6 percent of the world's grape growing area.Turkey is a major producer country of grapes growing in the world. Viticulture is one of the major branches of agriculture with respect to production area and its largest are of income in Turkish national economy. Since 1985, Turkey producing and exporting organic raisins, is a world leader in the production of raisins.

8418 hectares grape are grown organically which constitutes $1.8 \%$ of the total grape production area of Turkey.

The research was carried out in Alaşehir-Yeşilyurt Enterprise of Manisa Viticulture Research Institute in West Turkey from 2006 to 2007. In this study, effect of four different level of leaf removal applications at two periods on mineral substance of raisins at Sultani Çekirdeksiz grape variety growing organic conditions were investigated.

Experiment design were planed randomized block trial design with three replicates consisting of 12 vines per parcel were established. Mineral substance analyses of the raisins obtained from the applications were performed using the ICP-AES technique.

It was found that there was highest average potassium $(\mathrm{K})$, iron $(\mathrm{Fe})$ and $\mathrm{Zinc}(\mathrm{Zn})$ contents of the raisin in removing two leaves at berry set time down to the clusters; highest average magnesium $(\mathrm{Mg})$ and copper $(\mathrm{Cu})$ contents of the raisin in removing two leaves down to the clusters and removing two leaves up to the clusters at verasion time; highest average phosphorus $(\mathrm{P})$ contents of the raisin in no leaf removal; highest average sodium ( $\mathrm{Na}$ ) contents of the raisin in removing three leaves at the berry set time and removing three leaves at verasion time down and up to the clusters at $5 \%$ significant level.
\end{abstract}

\section{Introduction}

Turkey is a major producer of grapes in the world and viticulture is one of the major branches of agriculture with respect to production area and its large share of income in Turkish national economy. Grapevine is grown in almost all parts of Turkey and has been produced commercially in many regions of the country for many years.

311.595 hectares of organic grapes are grown, which constitutes 4.6 percent of the world's grape growing area [1].

Turkey is a major producer country of grapes growing in the world. Viticulture is one of the major branches of agriculture with respect to production area and its largest are of income in Turkish national economy. Since 1985, Turkey producing and exporting organic raisins, is a world leader in the production of raisins.

Vineyards where organic grapes are grown are generally located in the provinces of Izmir and Manisa, and almost all the grapes are dried and exported to European countries in particular [2].

\footnotetext{
${ }^{a}$ e-mail: fadimeates@gmail.com
}

8418 hectares grape are grown organically which constitutes $1.8 \%$ of the total grape production area of Turkey [1].

A study investigated the impact of organic and conventional viticulture applications under upland conditions on efficiency and quality. The results of the study have revealed that the efficiency and quality of the organically grown grapes were superior to those grown with conventional methods [3].

The removal of leaves in the fruit zone is one of the most important and commonly applied summer canopy management manipulation in viticulture. Leaf removal is performed on grapevines to increase air circulation, light exposure, penetration of fungicide sprays and decrease disease incidence, especially rot [4].

Plant management determines the spatial arrangement of foliage and clusters modifies the microclimate and has a fundamental impact on the regulation of photosynthetic potential, yield and grape composition [5].

Leaf removal is significantly reduced titratable acidity (TA g/L), sugar per berry, cluster weight, berry size, uptake of potassium and whole vine photosynthesis while juice $\mathrm{pH}$ increased [6-16]. 
The removal of leaves receiving low photosynthetic photon flux rate (PPFR) increased sugar levels and reduced titratable acidity, malate, $\mathrm{pH}$ and $\mathrm{K}+$ levels in must [17].

Several strategies for reporting and controlling vine balance have been proposed. An accepted definition of this equilibrium between crop load and vegetative growth is the leaf area required for maximizing the yield and ripeness. This equilibrium has been reported to range from $7 \mathrm{~cm}^{2} \mathrm{~g}$ 1 to $14 \mathrm{~cm}^{2} \mathrm{~g}-1$ [18] and between $8 \mathrm{~cm}^{2} \mathrm{~g}-1$ and $12 \mathrm{~cm}^{2}$ $\mathrm{g}-1$ [19] and $11,8 \mathrm{~cm}^{2} \mathrm{~g}-1$ [8] and 5-7 $\mathrm{cm}^{2} \mathrm{~g}-1$ [6].

Leaf removal directly affects the leaf/fruit relationship, which, depending on the phenological stage in which it is conducted, can produce a different effect on the maturation of the fruits $[12,20]$. The impact of basal leaf removal, usually involving the leaves positioned immediately above and below and opposite the fruit cluster, is clearly influenced by the number of leaves removed [21].

Basal leaf removal is one of the most common practices in canopy management $[6,8,14,22,23]$. It is frequently done during the ripening season if the canopy has a very high density, in an attempt to improve the colour intensity and aroma and to decrease the disease impact of pests $[7,22]$.

According to Considine and Considine [24] and also to Fidan and Yavaş [25], mineral substances found in grape are taken up from the soil by the vine and transferred to the plant and the fruit. In their study in which they observed quantities of macro-elements and micro-elements in must made from three Hungarian grape varieties during the course of ripening, Diófási et al. [26] stated that there was a positive correlation between the sugar quantity and N, P, $\mathrm{Ca}, \mathrm{Fe}$, and $\mathrm{Mg}$ elements.

Aykut [27] determined mineral substances found in musts of Sultani Çekirdeksiz, Muscat Hamburg and Alicante Bouschet grape varieties in $\mathrm{mg} / \mathrm{kg}$ as $1540-1750$ 1255 for K, 24-29.06-34 for $\mathrm{Ca}, 100-53.75-102.5$ for Mg, 53.30-31.32-52.15 for Na, 136.9-97.20-168.2 for P, 1.88-0.71-1.38 for $\mathrm{Fe}, 2.5-1.69-0.8$ for $\mathrm{Cu}, 0.68-0.79-$ 0.35 for $\mathrm{Zn}$ and $0.80-0.49-1.45$ for Mn, respectively.

Raisins (Vitis vinifera L.) have been a favorite food since $1490 \mathrm{BC}$ due to their nutritive value and high micronutrients content [28]. It was one of the most important and popular dried fruits in the world because their high nutritional value [29]. Raisins should be of particular interest in these investigations due to their unique phytochemical composition and the natural qualities that make raisins an appealing source of necessary minerals including potassium, iron, vitamin B, calcium, magnesium, sodium, arsenic, cadmium, chromium, manganese and nickel $[29,30]$.

Potassium (K) is a very important component for human health. High-potassium diet lowers blood pressure and reduces cardiovascular disease morbidity and mortality [31]. In addition, potassium intake lowers urinary calcium excretion and decreases the risk of osteoporosis [32].

Iron $(\mathrm{Fe})$ is an essential part of hemoglobin; the red colouring agent of the blood that transports oxygen through our bodies. Iron is needed for psychomotor development, maintenance of physical activity and work capacity, and resistance to infection [33].

Zinc is needed for growth and for maintenance of immune function, which enhances both the prevention of and recovery from infectious diseases [34].
The $\mathrm{Mg}$ is essential to all living cells, where they play a major role in manipulating important biological polyphosphate compounds like ATP, DNA, and RNA [32].

Phosphorus can be found in the environment most commonly as phosphates. Phosphates are important substances in the human body, because they are a part of DNA materials and they take part in energy distribution [35].

Sodium (Na) is a very important macronutrient of human body system. The most common dietary source of sodium is common table salt $(\mathrm{NaCl})$. It plays an essential role in the maintenance of normal physiology in all living organisms. A lack of sodium intake is incompatible with survival. An adequate intake of sodium is required for optimal growth. Distribution of intracellular and extracellular fluid volumes are dictated by sodium and either a deficiency or excess of sodium will alter overall fluid balance and distribution [36]. Na depletion is characterized by mood changes, muscle cramps, fatigue, hair loss, hypotension and dehydration [37].

The present study was conducted on Sultani Çekirdeksiz grape variety, which has an important place in our national economy. The objective of this study was to determine the effect of four different level of leaf removal applications at two periods on the nutrient contents of raisins produced from Sultani Çekirdeksiz grape variety in organic grape parcels during organic production phase (2006-2007). In addition to that research this study emphasized on the importance of raisins, organic raisins in particular, as a natural source of energy in human nutrition.

\section{Materials and methods}

\subsection{Materials}

\subsubsection{Experimental site}

Field experiments were conducted from 2006 to 2007 in Alaşehir-Yeşilyurt Enterprise of Manisa Viticulture Research Institute in West Turkey $\left(38^{\circ} 20^{\prime} \mathrm{N}, 28^{\circ} 38^{\prime} \mathrm{W}\right)$. The area has a transition towards a continental climate from a Mediterranean climate. The annual average temperature of $16.7^{\circ} \mathrm{C}$ and a mean annual rainfall of $598 \mathrm{~mm}$, The summer months, including the harvest period, are quite hot with mean temperatures of $30^{\circ} \mathrm{C}$.

Experiment design were planed randomized block trial design with three replicates which were established in 15 years old Sultani Çekirdeksiz vineyard under irrigable soil conditions and trained to " $\mathrm{T}$ " wire grape trellis training system and can-pruned to 60 buds per vine. The vines had between-row and within-row spacings of 3.3 and $2.4 \mathrm{~m}$, respectively in organic parcel.

\subsubsection{Sultani Çekirdeksiz grape variety}

Sultani Çekirdeksiz is a variety which ripens in midseason. It grows strong with conical clusters, wings, normal density, small oval shaped berries and average berry skin thickness. Although it is a variety for drying, Sultani Çekirdeksiz is also processed as table grapes through a series of culture practice. 
Table 1. Physical analysis and macronutrient and micronutrient contents of the soil sample.

\begin{tabular}{|l|l|l|}
\hline & \multicolumn{2}{|l|}{ Soil Depth } \\
\hline & $0-30 \mathrm{~cm}$ & $30-60 \mathrm{~cm}$ \\
\hline $\mathrm{pH}$ & 7.60 & 7.65 \\
\hline Soil salinity (\%) & 0.025 & 0.025 \\
\hline Lime (\%) & 3.44 & 3.92 \\
\hline Sandy (\%) & 68.40 & 66.40 \\
\hline Silt (\%) & 24.00 & 25.00 \\
\hline Clay (\%) & 7.60 & 8.60 \\
\hline Texture & Sandy-loam & Sandy-loam \\
\hline Organic Matter (\%) & 1.52 & 0.95 \\
\hline Total Nitrogen (\%) & 0.060 & 0.038 \\
\hline Available Phosphorus (ppm) & 3.32 & 1.29 \\
\hline Available Potassium (ppm) & 175 & 155 \\
\hline Available Calcium (ppm) & 2160 & 2400 \\
\hline Available Magnesium (ppm) & 934 & 938 \\
\hline Available Sodium (ppm) & 20.8 & 19.0 \\
\hline Available Iron (ppm) & 8.51 & 6.79 \\
\hline Available Copper (ppm) & 6.13 & 3.48 \\
\hline Available Zinc (ppm) & 0.67 & 0.52 \\
\hline Available Manganese (ppm) & 7.20 & 4.09 \\
\hline
\end{tabular}

\subsubsection{Soil composition of the trial vineyard}

There are no salinity problems whatsoever in soil samples demonstrating slight alkaline reaction. Soils with low lime level show a sandy loam texture. Available phosphorus in soils with low humus level and with medium total nitrogen level was found to be medium $(0-30 \mathrm{~cm})$ and low $(30-60 \mathrm{~cm})$, whereas available potassium was insufficient. In soils with sufficient (high) levels of available calcium and available magnesium, there are no problems with respect to available sodium. Available micronutrient elements in the soil samples including iron, copper and manganese were sufficient, whereas zinc was insufficient (Table 1).

\subsection{Methods}

Common vetch (Vicia sativa L.), Rye (Hordeum vulgare L.), and broad beans (fava beans) were used as mulch plants. In November, the soil was tilled using conventional method before planting mulch plants. The mix was planted by using fertilizer spreader. After planting, the soil was disked to incorporate the seeds with soil. The soil was tilled in spring and autumn in trial parcel.

The effect of four different level of leaf removal applications at two periods on organic grape production was examined. In this research control (no leaf removal); two leaf removal at berry set time; four leaf removal at verasion time; six leaf removal at the berry set time and at verasion time were used (Table 2).

Potassium $(\mathrm{K})$, phosphorus $(\mathrm{P})$, sodium $(\mathrm{Na})$, iron $(\mathrm{Fe})$, copper $(\mathrm{Cu})$, zinc $(\mathrm{Zn})$, manganese $(\mathrm{Mn})$, calcium $(\mathrm{Ca})$ and magnesium $(\mathrm{Mg})$ contents of the raisin samples were determined in a series of analyses carried out using an ICPAES spectroscopy during organic production phase from 2006 to 2007.

Mineral substance analyses were performed on raisin samples obtained from applications using an ICP-AES spectroscopy. A $10 \mathrm{~g}$ raisin sample is placed in a crucible and dried in an incubator at $100^{\circ} \mathrm{C}$. The samples
Table 2. Applied leaf removal methods.

\begin{tabular}{|c|c|}
\hline Applications & Method \\
\hline Kontrol & No leaf removal \\
\hline $\begin{array}{l}\text { Two leaf removal } \\
\text { (B-2) }\end{array}$ & $\begin{array}{l}\text { Removing two leaves at berry set } \\
\text { time down to the clusters }\end{array}$ \\
\hline $\begin{array}{l}\text { four leaf removal } \\
(\mathrm{V}-4)\end{array}$ & $\begin{array}{l}\text { Removing two leaves down to the } \\
\text { clusters and removing two leaves } \\
\text { up to the clusters at verasion time }\end{array}$ \\
\hline $\begin{array}{l}\text { Six leaf removal } \\
(B+V-6)\end{array}$ & $\begin{array}{l}\text { Removing three leaves at the berry } \\
\text { set time and removing three leaves } \\
\text { at verasion time down and up to } \\
\text { the clusters }\end{array}$ \\
\hline
\end{tabular}

Table 3. P, K, Mg and Ca contents of each parcel under different leaf removal level.

\begin{tabular}{|l|c|c|c|c|}
\hline $\begin{array}{l}\text { LEAF } \\
\text { REMOVAL } \\
\text { METHODS }\end{array}$ & $\begin{array}{c}\mathbf{P} \\
(\mathbf{p p m})\end{array}$ & $\begin{array}{c}\text { K } \\
(\mathbf{p p m})\end{array}$ & $\begin{array}{c}\text { Mg } \\
(\mathbf{p p m})\end{array}$ & $\begin{array}{c}\text { Ca } \\
(\mathbf{p p m})\end{array}$ \\
\hline B-2 & $132.3 \mathrm{bc}$ & $8179.0 \mathrm{a}$ & $539.0 \mathrm{~cd}$ & 235.8 \\
\hline V-4 & $139.6 \mathrm{~b}$ & $7157.3 \mathrm{~b}$ & $617.6 \mathrm{a}$ & 253.2 \\
\hline B+V-6 & $140.3 \mathrm{~b}$ & $7573.4 \mathrm{~b}$ & $584.3 \mathrm{~b}$ & 240.0 \\
\hline Kontrol & $141.5 \mathrm{a}$ & $6948.9 \mathrm{c}$ & $563.0 \mathrm{c}$ & 247.8 \\
\hline
\end{tabular}

Kontrol: No leaf removal.

B-2: Removing two leaves at berry set time down to the clusters.

V-4: Removing two leaves down to the clusters and removing two leaves up to the clusters at verasion time.

B+V-6: Removing three leaves at the berry set time and removing three leaves at verasion time down and up to the clusters.

Values in the same column with different subscript letters represent significant differences between production phases.

are then put into the oven when their temperature reaches $250{ }^{\circ} \mathrm{C}$ and the temperature is raised to $600{ }^{\circ} \mathrm{C}$. They are left at this temperature overnight (13-15 hours). If the samples are not reduced to white ash, they are moistened with and dried in the oven for another 2 hours until they turn white. The crucibles are put in a desiccator and allowed to cool to room temperature. Later $6 \mathrm{ml}$ extraction acid $(\mathrm{HCl}+\mathrm{HNO} 3)$ and $50 \mathrm{ml}$ distilled water are added to the crucibles and slightly heated to dissolve the ashes. The solution is strained into $100 \mathrm{ml}$ volumetric flask using a black band filter and filled to the top with distilled water (The dilution factor should be 10.)

Desired standards are entered and the device is conditioned. Samples which have passed through the dilution procedure are fed into the device and Potassium $(\mathrm{K})$, phosphorus $(\mathrm{P})$, sodium $(\mathrm{Na})$, iron $(\mathrm{Fe})$, copper $(\mathrm{Cu})$, zinc $(\mathrm{Zn})$, manganese $(\mathrm{Mn})$, calcium $(\mathrm{Ca})$ and magnesium $(\mathrm{Mg})$ minerals are read using the emission technique. The results obtained are multiplied by SF and mineral substance quantities are found.

The research was carried out as randomized block design trials with three replicates consisting of 12 vines per parcel. After a variance analysis was performed on the data obtained was using the statistical software package "SPSS 20.0 for Windows", and the Tukey test $(\mathrm{p}<0.05)$ was used for comparison of average values.

\section{Results and discussion}

Mineral contents of each parcel under different leaf removal level are given in Table 3 and Table 4. 
Table 4. $\mathrm{Na}, \mathrm{Fe}, \mathrm{Cu}, \mathrm{Mn}$ and $\mathrm{Zn}$ contents of each parcel under different leaf removal level.

\begin{tabular}{|l|c|c|c|c|c|}
\hline $\begin{array}{l}\text { LEAF } \\
\text { REMOVAL } \\
\text { METHODS }\end{array}$ & $\begin{array}{c}\text { Na } \\
(\mathbf{p p m})\end{array}$ & $\begin{array}{c}\text { Fe } \\
(\mathbf{p p m})\end{array}$ & $\begin{array}{c}\mathbf{C u} \\
(\mathbf{p p m})\end{array}$ & $\begin{array}{c}\text { Mn } \\
(\mathbf{p p m})\end{array}$ & $\begin{array}{c}\mathbf{Z n} \\
(\mathbf{p p m})\end{array}$ \\
\hline B-2 & $130.9 \mathrm{c}$ & $21.8 \mathrm{a}$ & $5.5 \mathrm{~b}$ & 2.1 & $8.0 \mathrm{a}$ \\
\hline $\mathbf{V - 4}$ & $175.3 \mathrm{~b}$ & $19.4 \mathrm{~b}$ & $7.2 \mathrm{a}$ & 2.3 & $7.1 \mathrm{~b}$ \\
\hline B+V-6 & $184.0 \mathrm{a}$ & $14.8 \mathrm{c}$ & $5.9 \mathrm{~b}$ & 2.3 & $6.3 \mathrm{c}$ \\
\hline Kontrol & $142.8 \mathrm{bc}$ & $19.4 \mathrm{~b}$ & $6.2 \mathrm{~b}$ & 2.0 & $7.2 \mathrm{~b}$ \\
\hline
\end{tabular}

Kontrol: No leaf removal.

B-2: Removing two leaves at berry set time down to the clusters.

V-4: Removing two leaves down to the clusters and removing two leaves up to the clusters at verasion time.

$\mathrm{B}+\mathrm{V}-6$ : Removing three leaves at the berry set time and removing three leaves at verasion time down and up to the clusters.

Values in the same column with different subscript letters represent significant differences between production phases.

According to the results of the statistical analysis, it was determined that leaf removal level over the years had different important effects on the phosphorus (P), potassium $(\mathrm{K})$, magnesium $(\mathrm{Mg})$, sodium $(\mathrm{Na})$, iron $(\mathrm{Fe})$, copper $(\mathrm{Cu})$ and zinc $(\mathrm{Zn})$ contents of the organic raisins at $5 \%$ significance level.

As can be seen from Table 4, removing two leaves at berry set time down to the clusters, comparing the other leaf removal level, had the highest amount of potassium $(\mathrm{K})$, iron $(\mathrm{Fe})$ and zinc $(\mathrm{Zn})$ contents of the raisin as $8.179,0,21.8,8.0 \mathrm{ppm}$, respectively. These results are similar to those reported by Adamyan, [38]; Bergqvist et al. [39], Yağciand İlter [40], Emine et al. [41] and Gary and Arianna [42] and Simsek et al. [30] in seedless raisin.

Removing three leaves at the berry set time and removing three leaves at verasion time down and up to the clusters only increased the amount of magnesium $(\mathrm{Mg})$ and copper $(\mathrm{Cu})$ contents of the raisin, as $617.6 \mathrm{ppm}$ and $7.2 \mathrm{ppm}$, respectively whereas Removing three leaves at the berry set time and removing three leaves at verasion time down and up to the clusters generally had the lowest values of all minerals. No leaf removal (control) could only increase Phosphorus (P) (ppm) contents of the raisin, as $141.5 \mathrm{ppm}$. removing three leaves at the berry set time and removing three leaves at verasion time down and up to the clusters had the highest average sodium (Na) contents of the raisin as $184.0 \mathrm{ppm}$ (Table 4). These results are similar to those reported by Adamyan, [38] and Bergqvist et al. [39] and Simsek et al. [30] and also Yagci and İler [40].

When we compare the leaf removal level, it was observed that removing two leaves at berry set time down to the clusters increased potassium $(\mathrm{K})$, iron $(\mathrm{Fe})$ and Zinc $(\mathrm{Zn})$ contents of the raisin and removing two leaves down to the clusters and removing two leaves up to the clusters at verasion time increased magnesium $(\mathrm{Mg})$ and copper $(\mathrm{Cu})$ contents of the raisin and no leaf removal phosphorus (P) contents of the raisin and also in removing three leaves at the berry set time and removing three leaves at verasion time down and up to the clusters increased sodium (Na) contents of the raisin.

According to the overall results of this research; it could be concluded that leaf removal applications level in organic raisins effected positively and organic raisin constitute a natural source of energies and many minerals such as phosphorus $(\mathrm{P})$, potassium $(\mathrm{K})$, magnesium $(\mathrm{Mg})$, sodium $(\mathrm{Na})$, iron $(\mathrm{Fe})$ and Zinc $(\mathrm{Zn})$, that may prevent many diseases [31,32,32-37].

\section{References}

[1] http://www.organic-world.net/yearbook2015.html

[2] Altindisli A., 2. International Conference on Organic Farming. 7-9 May 2004, Thiava, Greece

[3] Pamuk, H., Yuvarlak Çekirdeksiz Üzüm Bağlarında Çevre Dostu ve Geleneksel Tarım Uygulamalarının Verim ve Kaliteye Etkileri Üzerine Araştırmalar (Unpublished doctoral thesis-1999)

[4] Poni, S., Casalini, L., Bernizzoini, F.S. Civardi, and Intrieri, C., Am. J. Enol. Vitic. 57:397-407 (2006)

[5] Katerji, N., F. Daudet, A. Carbonneau, and Ollat, N., Vitis 33, 197-203 (1994)

[6] Uslu, .I, Journal of the Yalova Horticultural Research and Training Center 10 (2): 14-21 (1981)

[7] Bledsoe, A., Kliewer, W, and Marois, J., Am. J. Enol. Vitic.39:49-54 (1988)

[8] Kader, S., Yuvarlak Çekirdeksiz Üzüm Çeşidinde Yaprak Üzüm İlişkileri Üzerinde Araştırma. (Unpublished doctoral thesis-1990)

[9] Morrison, J. and Noble, A., American Journal of Enology and Viticulture. 41, 193-200 (1990)

[10] Kliewer, W.M., Marois, J.J., Bledsoe, A.M., Smith, S.P., Benz, M.J. and Silvestroni, O., Proceedings of the Second International Symposium for Cool Climate Viticulture and Oenology, NZ, Auckland, pp. 123-126 (1988)

[11] Ollat, N. and Gaudillere, J., American Journal of Enology and Viticulture. 49, 251-258 (1998)

[12] Iacono F., Bertamini M., Scienza A. and Coombe B.G., Vitis, 34, 201-206 (1995)

[13] Petrie, P.R., Trought, M.C.T. and Howell, G.S. and Buchan, G., Functional Plant Biology. 30, 711-717 (2003)

[14] Ateş, F., 2008. Effect of Some Cultural Applications on Vegetative Development, Yield, Fruit Quality in Cardinal, Pembe Gemre and Sultani Çekirdeksiz Grape Varieties. Manisa Viticulture Research Institute publications

[15] Poni, S., Bernizzoni, F., Civardi, S. and Libelli, N., American Journal of Enology and Viticulture. 15, 185-193 (2009)

[16] Pereira, G., Gaudillere, J., Pieri, P., Hilbert, G., Maucourt, M., Deborde, D., Moing, A. and Rolin, D., 54, 6765-6775 (2006)

[17] Hunter, J. and Visser. H., S. Afr. J. Enol. Vitic. 11: 26-32 (1990)

[18] Howell, G.S., Am. J. Enol. Vitic. 52:165-17. (2001)

[19] Kliewer, M., and Dokoozlian, N., Am. J. Enol Vitic. 56:170-181 (2005)

[20] Petrie P.R., Trought M.C.T. and Howell G.S., Vitis, 39, 31-36 (2000)

[21] Candolfi-Vasconcelos, M.C. and Koblet, W., Vitis 29:199-221 (1990)

[22] Percival, D.C., Fisher, K.H. \& Sullivan, J.A., Am. J. Enol. Vitic. 45, 133-139 (1994) 
[23] Tardáguila, J., Diago, M.P., Martínez de Toda, F., Poni, S. \& Vilanova. M., J. Int. Sci. Vigne Vin. 42, 221-229 (2008)

[24] Considine, D. M. and Considine, G. D., Foods and Foods Production Encyclopedia (1982)

[25] Fidan, Y. ve Yavaş, İ., 1th International Symposium on Food 10-13

[26] Diófási, L., Ijjász, I. and Vezekényi, E., 33 (1): 1-10, Hort. Abst. 56, 9, 732 ( 1986)

[27] Aykut, O., 2002, Ülkemiz Ekonomisinde Yeri Olan Üzüm Çeşitleri ile Ürünlerinin Mineral Madde İçerikleri ve Değişimi Etkileyen Faktörler (master's thesis 2002)

[28] Witherspoon, B., School Foodserv. Nutr. 54, 60-63 (2000)

[29] Fang, Y., Zhang, A., Wang, H., Li, H., Zhang, Z., Chen, S., Luan, L., Food Control. 21, 732-739 (2010)

[30] Simsek, A., Artık, N., Baspina, E., J. Food Comp. Anal. 17, 155-163 (2004)

[31] Whelton, P., He, J., Cutler, J., Brancati, F., Appel, L., Follmann, D., Kleg, M., J. Am. Med. Assoc. 277, 1624-1632 (1997)
[32] He, F., MacGregor, G., J. Plant. Biol. 133, 725-735 (2008)

[33] Stoltzfus, R. J. The Journal of nutrition, 131(2), 565S-567S (2001)

[34] Black R.E. J Nutr.133:1485S-1489S (2003)

[35] De Rosa, C. T., Pohl, H. R., Williams, M., Ademoyero, A.A.,Chou, C-H. S. J and Jones, D.E., Toxicological Defense Mechanics 394 p. (1998)

[36] Morris M. J., Na S. E and Johnson A. K., Physiology and Behavior, 94, 709-721 (2008)

[37] Harper M. E., Willis J. S. and Patrick J., Handbook of nutritionally essential minerals. 93-116 (1997)

[38] Adamyan, A. KH., Hort. Abst. Vol: 58, 5. 85-90 (1988)

[39] Bergqvist, J., Dokoozlian, N. and Ebisuda, N., American Journal of Enology and Viticulture. 52, 1-7 (2001)

[40] Yağc1, A. ve İlter, E., Türkiye V. Inational Hotriculture Congress, 459-461 (2007)

[41] Emine, S., Duygu, A., Ecehan, T., Nilgun, G., Ind. Crops. Prod. 34, 994-998 (2011)

[42] Gary, W., Arianna, C., Nutr. Res. 30, 511-519 (2010) 